\title{
Determinants of Passengers Satisfaction in the Public Transport Services: The Case of Dawuro Zone Bus Station, Southern Ethiopia
}

\author{
Lidetu Alemu Anjulo (Assistant Professor) \\ Lecturer, Department of Management, Woalita Sodo University, Southern Ethiopia \\ P.o.box: 138 Wolita Sodo \\ Legesse Kassahun Gebeyehu \\ MBA Graduate from Wolaita Sodo University, Southern Ethiopia
}

\begin{abstract}
Transport contributes greater share to the country's economic development. But the supply of transport services in Ethiopia in general and Dawuro in particular not satisfied the need of passengers. Therefore, the main objective of this study aimed to determinants that affecting passenger's satisfaction in public transport services the case of Dawuro bus station. Both quantitative and qualitative data types were used. The data were collected from 385 sample passengers through interview and group discussions by using questionnaires and checklists. This was supplemented by secondary data collected from different published and unpublished sources. Convenience sampling technique was employed. The data was analyzed by using descriptive statistics such as mean, percentages and standard deviation presented by using charts and tables. Correlation was also used to test the strength of the relationship between the two variables. From the econometrics analysis multiple linear regression and analysis of variance employed to test the hypothesis. Among the variables included in the model, services provided, fare system, accessibility, transport comfort, scheduled timings, availability facilities; terminal environment were significantly influence in public transport services. With respect to the problems that face passengers using public transport services steepness of the road, highest number of passengers or over load, attitudes of the drivers and bus owners were major problems in public transport service. Based on the research findings, recommendations are given to Dawuro Bus station in the last chapter
\end{abstract}

Keywords: Satisfaction, Public transport service and Passengers

DOI: $10.7176 / \mathrm{PPAR} / 9-11-02$

Publication date: November $30^{\text {th }} 2019$

\section{INTRODUCTION}

\subsection{BACKGROUND OF THE STUDY}

Transport is one of the complex services which contributes greater share to the country's economic development everybody travels whether it be work, play, and shop or do business. All raw materials must be conveyed from the land to a place of manufacture or usage, and all goods must be moved from the factory to the market place and from the staff to the consumer. Transport is the means by which these activities occur; it is the cement that binds together communities and their activities. Meeting these needs has been and continues to be the Transport task (Bell, et al., 2006). Transportation is the movement of people with goods from one place to the other. It is a means by which goods like raw material, production equipment, operating inventories, semi-finished goods and finished goods as well as people are able to get to or be made available where they are needed for commercials or non-commercial purposes, as at when desired. To achieve the welfare of human being the mobility or transportation of people and materials is vital for social interaction, co-operation, production activities, economic and other types of development. This is the reason why road transport is popularly referred to as the engine and wheel of the society and it helps the world to go round and function actively (Olakunori, 2006).

Moreover, to achieve the welfare of human being the mobility or transportation of people and materials is vital for social interaction, co-operation, production activities, economic and other types of development. This is the reason why road transport is popularly referred to as the engine and wheel of the society and it helps the world to go round and function actively (Olakunori, 2006). Transport routes between places facilitates the movement of goods and people between nodes; they often become linier nodes themselves (Asnake, 2006). Transport provides a means of moving persons from one place to another. Thus, it would be possible to say that, people use transport to satisfy a particular need, i.e. the need to get to work and back to home (Bamford and Robinson, 1978; Wood and Johnson, 1989).

Public transport is a shared passenger transport service available for the use of general public for the purpose of travelling from an origin to a destination. Public transport modes may include buses, trains, rapid transits, trams, ferries and air carriers, depending on countries requirements (Ranawana and Hewage, 
2015). It is important to improve the public transport services to satisfy customers. In many countries, major investments are being made in public transport systems to make them more competitive. However, an increase in supply will not automatically lead to a corresponding increase in demand and satisfaction (Fujii and Kitamura 2003). To make sure that investment really attracts both the existing and the potential customers envisaged, knowledge of satisfaction and service performance should provide policymakers and operational managers in public transport with valuable information.However, in order to keep and attract more passengers, public transport must to have high service quality to satisfy and fulfill more wide range of different customer's needs (Oliver 1980; Anable 2005). It is important to summarize knowledge about what drives customer satisfaction and dissatisfaction in public transport area to design an attractive and marketable public transport. An improvement of supplied service quality can attract additional users from other modes of transport such as private transport modes(Laura Eboli, Gabriella Mazzulla, 2007).

Passenger's satisfaction is defined as a judgment that a product or service is provided at a pleasurable level of consumption-related fulfillment. Generally, people tend to be satisfied when their perceptions of the service they receive match their expectations, and these expectations could be subjective or objective. When service quality falls short of expectations they tend to be dissatisfied (Mintesnot G. et al., 2011). The goal of public transport needs to include the development of practical tools that improve the quality of people's mobility and daily life (Maria Morfoulaki, et al., 2007). It is an undeniable fact that mobility is part of the daily round of activities and as such an essential component of the life of every human being (Albalate and Bel, 2010). In satisfying the need to move, public transport has in recent times become the most commonly used mode of transport. Therefore, the ways public transport services are delivered as well as their qualities are important because of their effect both on the attitude and behavior of travelers and the demand for services. Public transport services are mostly delivered either by private or public organizations. Regardless of the party that delivers them, public transport services require substantial investment and high operating costs.

Palmer and Cole (1995), state that "service is the production of essentially intangible benefits which through some form of exchange satisfies an identified consumer's need. Consequently, there are service providers to satisfy customers' needs. Rosander (1985), Daniels (1993), and Zeithaml and Bitner (2004) have grouped transportation under the category of services.

\subsection{STATEMENT OF THE PROBLEM}

Public transport is significant for economic growth and economic development since it facilitates the movement of labor, raw materials, finished commodities and creation of employment in the economy (Cavanna and Cornbelt, 2007) the public transport permits firms and people that do not own units of carriage to transport their commodities (Poleen 1993). The organizations and people that use public transport need to be assured that their goods will reach the desired destinations and in good time (Annabel 2005). Public transport should become part of a solution for sustainable transport in the future. However, in order to keep and attract more passengers, public transport must to have high service quality to satisfy and fulfill more wide range of different customer's needs (Anable 2005). It is important to summarize knowledge about what drives customer satisfaction in public transport area to design an attractive and marketable public transport

The Ethiopian Federal Transport Authority (2011) was shown that the sector is facing certain challenges because the entire people of the nation highly lie on road transport than other alternative modes. The demand for transport service, however, has been increasing from time to time in Ethiopia. There is also a prevalence of poor quality of services in the sector which makes the road transport passengers of the nation dissatisfied. Demand and supply of transport services could not be matched. Delivering quality transport service to the public with adequate capacity that can meet and satisfy their requirements. But, existing studies on transport carried out in the nation do not properly address the issue under customer satisfaction in public transport services. When service quality falls short of expectations they tend to be dissatisfied (Mintesnot G. et al., 2011).

There are huge public transport services problems in local level. For example, the major modes of public transportation are in buses and vehicles. The population of Dawuro is increasing significantly, customer satisfaction in public transport services not attained. Moreover, the supply of transport service is not proportional to the demand. There was little investigation in areas of transport service quality and customers' satisfaction in public road transport sector of Dawuro zone. Therefore, this study was intended to assess factors affecting passengers' satisfaction in public transport services in Dawuro bus stations.

\subsection{OBJECTIVES OF THE STUDY}

\subsubsection{General Objective}

This research study mainly focuses on determinants which affecting passenger's satisfaction in public transport services.

\subsubsection{Specific Objectives}

$>$ To analyze the level of satisfaction of passengers using the public transport services. 
To identify the problems that face passengers using public transport services.

\subsection{RESEARCH QUESTIONS}

To address the above stated problems the researcher designed the following basic questions:

1. What are the determinants which affect passenger satisfaction using public transport service?

2. What are the problems travelers faces in the current transport system?

\subsection{RESEARCH HYPOTHESIS}

H01: A services provided has no significant effect on passengers satisfaction in the study area.

H02: Access to service has no significant effect on passenger's satisfaction in the study area

H03: Availability of facilities has no significant effect on passenger's satisfaction in the study area

H04: scheduled timings has no significant effect on passenger's satisfaction in the study area.

H05: Terminal environment has no significant effect on passenger's satisfaction in the study area.

H06: Transport comfort has no significant effect on passenger's satisfaction in the study area.

H07: Fare system has no significant effect on passenger's satisfaction in the study area.

\section{Literature Review}

\subsection{FACTORS AFFECT PASSENGERS SATISFACTION}

1. Services provided: means information, staff behavior, safe from accident, information in bus stop etc. Those passengers who use bus transportation services are increasingly sensitive to waiting time and they are more satisfied with scheduled service, which habitually operates exactly according to scheduled departure and arrival times by operating at the appropriate frequency. The primary determinant of service reliability is the reliability of the vehicle itself (Ranawana and Hewage, 2015). Availability of passengers to use buses for their daily traveling needs. Poor reliability within an operation is the result of several breakdowns, which in turn has adverse effect on vehicle availability and affects the quality and quantity of the overall services

2. Accessibility: can be expressed in terms of the distance passengers have to walk starting from their home to the initial bus stops and from the final bus stops to their final destination. Accurate and up-to-date information increases passengers satisfaction and it may also persuade additional passengers to use the service (Iles, 2005). Beirão (2007) conducted depth interviews in Porto to find out dissatisfying factors. The results showed that customers reported a lot of waste time in distance from home to terminal, too crowded, lack of comfort, time uncertainty, lack of control, unreliability, long waiting times, need to transfer, they cannot change route to avoid traffic congestion, lack of flexibility, and long walking time.

study are

3. Availability of facilities: enables passengers to plan their journeys, especially for prospective passengers. Details of routes operated, points at which vehicles may load and unload passengers, places served along each routes, final destinations of routes, and service operation time-tables which include departure times from terminals, times at major intermediate stops and arrival times at the destination are important information that should be made available to passengers (Ranawana and Hewage, (2015).

4. Scheduled timings: which consist of public bus transport departure frequency, travel time, punctuality etc.Waiting time is the time passengers have to wait at bus stops for buses (World Bank, as cited in ArmstrongWright, 1993). Even though, their expectations may vary, most passengers are delighted with minimum waiting time. The shorter the waiting time is the greater the level of convenience (Iles, 2005).

5. Terminal environment: which means cleanliness, bus stop security, on board security, bus stop condition etc. While the presence of inspectors or conductors on the vehicles, good lighting on buses and at bus stops have a beneficial effect in reducing the opportunities for the crime of pick pocketing, overcrowding of buses and poor discipline at bus stops and terminals increases passengers vulnerability to pickpockets (Iles, 2005). On public buses particularly, stealing is common and people lose their wallets due to pick pocketing.

6. Transport comfort: This includes bus comfort, seat availability. Good seats with available space to move easily, good heating and ventilation systems, high proportion of seated to standing passengers, low step heights (to facilitate access by disabled passengers), good maintenance standards so that the interiors of buses are in a good state of repair and good standards of cleanliness, low level of crowding, smoothly driven buses particularly where standing passengers are carried, good protection and resting facilities for waiting passengers at bus stops and stations, good discipline at bus stops and on boarding the vehicle so that passengers are being protected from jostling or losing their places in a queue are highly required by passengers and determine their level of comfort and satisfaction (Iles, 2005; Height and Cresswell, 1979).

7. Fare system: which is the price paid for availing the transport facility? A system which requires passengers to have the exact fare ready when boarding the bus and advance purchase of tickets from road side vending machines are common in most countries. Whatever the system of payment, it should be easy and more userfriendly than others (Bielen and Demoulin (2007): Iles, 2005). Beirão \& Sarsfield Cabral (2007) summarizes 
advantages in using public transport according to Portugal public transport users. The result highlights the importance of a cost friendly and reasonable fare system and less stressful public transport service.

\subsection{CONCEPTUAL FRAMEWORK}

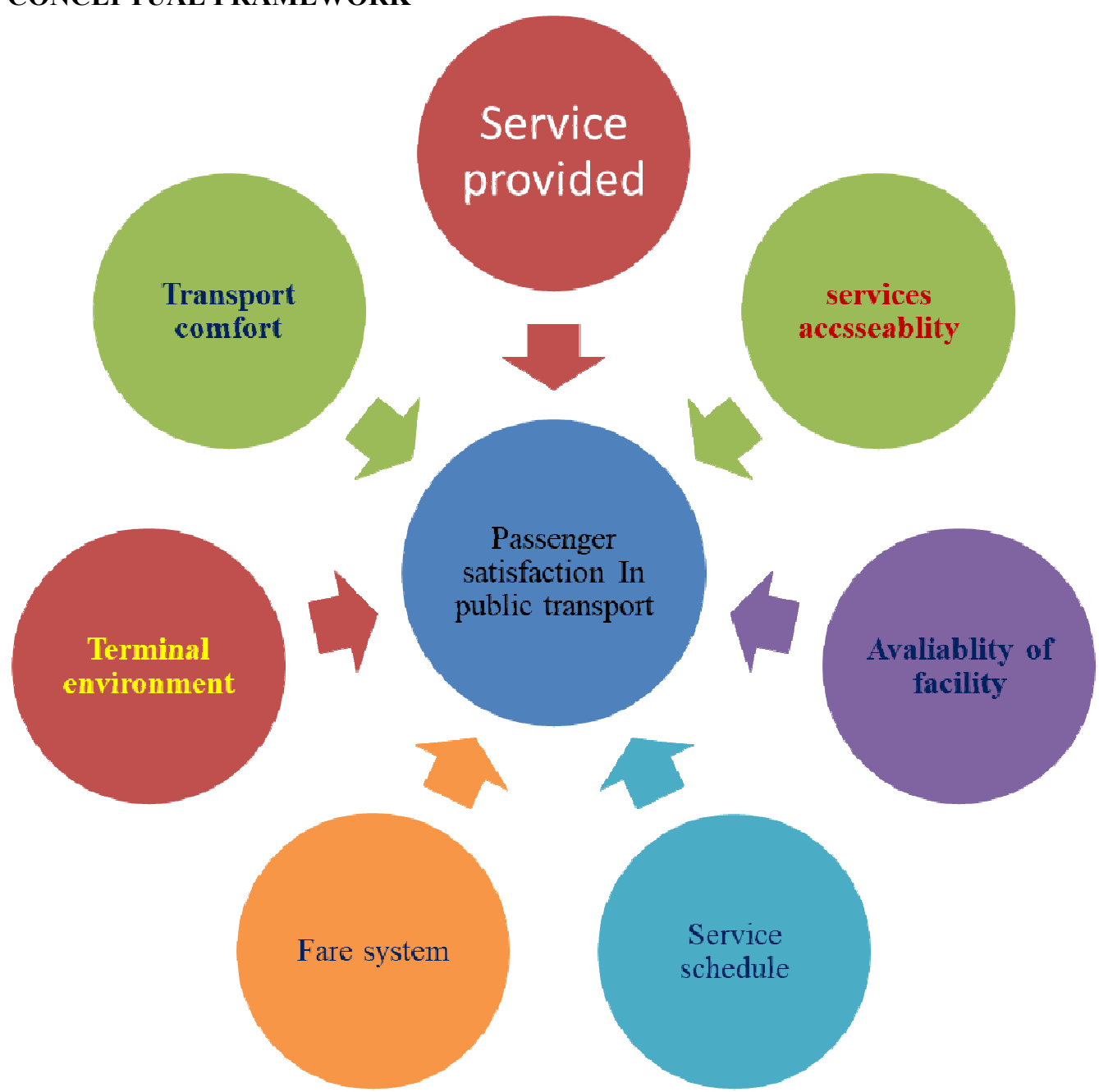

Figure 1: Conceptual Framework of passenger satisfaction on public transport

(Source Researchers own design, 2019)

\section{RESEARCH METHODOLOGY}

\subsection{Research Design}

For this research work, the researcher had used cross sectional in design since data was collected at one point of time. In cross-sectional field surveys, independent and dependent variables are measured at the same point in time using a single questionnaire (Anol, 2012).

\subsection{Data Sources}

There are two major research approaches namely, quantitative and qualitative, where one of them is not better than the others, rather depends on how the researcher wants to do a research of study (Ghauri and Kjell, 2005).

Both quantitative and qualitative data was collected. The data collected through questionnaire have closed an ended question which was measured on continuous scale and interview for Semi-structured questions. Thus, quantitative and qualitative research methodology will apply in this research.

\subsection{Target Population}

The population for the study is infinite population. The passengers availing the public transport facility from Dawuro Bus station cannot be definitely ascertained.

\subsection{Sampling Technique}

For this study, the researcher used Convenience sampling as the total population is infinite. For this study 
member of the target population that meet certain practical criteria, such as easy accessibility, availability at a given time, or the willingness to participate are included for the purpose of the study. It is also called as accidental sampling or opportunity sampling. The researcher includes those participants who are easy or convenient to approach. The technique is useful where target population is defined in terms of very broad category. For instance the target population may be girls and boys, men and women, rich and poor

Method: Any member of the target population who is available at the moment is approached he or she is asked for participation in the research.

\subsection{Sampling size}

As the population of the study is infinite and the passengers availing the public transport facility from Dawuro bus station cannot be definitely ascertained. Therefore, sample size to collect data through questionnaire for this research was determined by using Cochran method of sample determination for infinite population at $95 \%$ confidence level.

$\mathbf{n}=\frac{z^{2} p q}{a^{2}}$

Where,

$\mathrm{n}=$ Sample Size $\mathrm{p}=$ the estimated proportion of an attribute

$\mathrm{Z}=$ Standard Normal Variate $=$ standard error associated with the chosen level of confidence $(1.96) \mathrm{q}=1-\mathrm{p}$ e $=$ Significance Level

$\mathrm{n}=\left(\underline{1.96)^{2} * 0.50 * 0.50=384.16}=385\right.$ passengers

$$
(0.05)^{2}
$$

\subsection{Mathematical Model}

The mathematical model can be written as:

$\mathrm{Y}=\mathrm{a}+\beta \mathrm{x}$

Where, $Y=$ dependent variable; $a=$ intercept; $\beta=$ slope (coefficient) of independent variable $\mathrm{x}$

$\mathrm{CSPT}=\mathrm{a}+\beta 1 \mathrm{X} 1+\beta 2 \mathrm{X} 2+\beta 3 \mathrm{X} 3+\beta 4 \mathrm{X} 4+\beta 5 \mathrm{X} 5+\beta 6 \mathrm{X} 6+\beta 7 \mathrm{X} 7+\mathrm{U}$

Where

CSPT $=$ Customer Satisfaction on Public Transport

$\mathrm{X} 1$ = Services provided,

$\mathrm{X} 2$ = Services accessibility,

X3 = Availability of facilities,

$\mathrm{X} 4=$ Services Schedule,

$\mathrm{X} 5=$ Terminal environment

$\mathrm{X} 6=$ Transport comfort

$\mathrm{X} 7=$ Fare system

$\mathrm{U}=\mathrm{It}$ is the Stochastic Disturbance term/ a random and unobserved that may represent all other challenging factors.

\section{DATA PRESENTATION, ANALYSIS AND INTERPRETATION}

This chapter deals with presentation, analysis and interpretation of data collected from 385 sampled respondents. This part mainly concerns the demographic characteristic of the respondents, analysis of independent variables with respect to the customer satisfaction which was analyzed by using frequencies, percentages and the factors that affect the satisfaction of the public transport were analyzed by multiple linear regression model.

\subsection{General Characteristics of the Respondents}

Table 4.1: Age category of the respondents.

\begin{tabular}{|c|l|l|}
\hline Age group & Frequency & Percent \\
\hline $18-20$ & 56 & 14.5 \\
$21-30$ & 101 & 26.2 \\
$31-40$ & 127 & 33.0 \\
$41-50$ & 81 & 21.0 \\
Above 50 & 20 & 5.2 \\
Total & 385 & 100.0 \\
\hline
\end{tabular}

Source: own survey data, 2019

With regarding to age, $56(14.5 \%)$ of the respondents are in the range of $18-20$ years, $101(26.2 \%)$ are in the range of 21-30 years, $127(33 \%)$ are in the range of 31-40 years, $81(21 \%)$ are in the range of 41-50 years and 20 $(5.2 \%)$ were above 50 years as indicated in (Table 4.1$)$. The result revealed that the majority of the passengers 
range in age of 31-40 years.

Table 4.2: The frequency of travelling public transport

\begin{tabular}{|l|l|l|}
\hline & Frequency & Percent \\
\hline Daily & 78 & 20.3 \\
Weekly & 164 & 42.6 \\
once a month & 125 & 32.5 \\
every 2-3 months & 10 & 2.6 \\
once a year & 8 & 2.1 \\
Total & 385 & 100.0 \\
\hline
\end{tabular}

Source: Own survey data,2019

Table 4.2 showed the frequency of travelling with public transport. From the total respondents, 78 (20.3\%) of the respondents are travelling daily, $164(42.6 \%)$ are travelling weekly, $125(32.5 \%)$ are travelling once a month, $10(2.6 \%)$ are travelling every 2 - 3 months and $8(2.1 \%)$ are travelling once a year. From this, it can be understood that travels availing the public transport from Dawuro bus terminal is a mix of all commuters who are travelling at different intervals of time with majority at weekly $(42.6 \%)$.

Table 4.3: Income level of the passengers

\begin{tabular}{|l|r|r|}
\hline Income range & Frequency & \multicolumn{1}{|c|}{ Percent } \\
\hline less than 1000 & 20 & 5.2 \\
\hline $1001-2500$ & 120 & 31.2 \\
\hline $2501-5000$ & 101 & 26.2 \\
\hline $5001-7500$ & 93 & 24.2 \\
\hline $7501-10000$ & 50 & 13.0 \\
\hline above 15000 & 1 & .3 \\
\hline Total & 385 & 100.0 \\
\hline
\end{tabular}

Source: own survey data, 2019

The Table 4.3 indicated the level of income. From the total respondents, $20(5.2 \%)$ of the respondents are in the range of less than $1000,120(31.2 \%)$ are in the range of 1001-2500, $101(26.2 \%)$ are in the range of 2501$5000,93(24.2 \%)$ are in the range of $5001-7500,21(5.5 \%)$ are in the range of $7501-10000,50(13 \%)$ are in the range of $10001-15000$, and $1(0.3 \%)$ are above 15000 birr. From this result, it can be understood that majority of respondents $(31.2 \%)$ ranges in income level of 1001-2500 birr.

\subsection{Analysis of independent variables.}

The results presented in frequency and percentages of respondents the items that measured and rated on a fivepoint Likert scale $(1=$ strongly disagree $2=$ disagree $3=$ medium $4=$ agree $5=$ strongly agree $)$.

Table 4.2.1: services provided

\begin{tabular}{|c|c|c|c|c|c|c|c|}
\hline & ITEM & & $\begin{array}{l}\text { Strongly } \\
\text { disagree }\end{array}$ & Disagree & Neutral & Agree & $\begin{array}{l}\text { Strongly } \\
\text { agree }\end{array}$ \\
\hline \multirow[t]{2}{*}{1.1} & \multirow{2}{*}{$\begin{array}{l}\text { The terminal has safe and competent drivers } \\
\text { and Conductors }\end{array}$} & $\mathrm{N}$ & 91 & 173 & 31 & 90 & 0 \\
\hline & & $\%$ & 23.6 & 44.9 & 8.1 & 23.4 & 0 \\
\hline \multirow[t]{2}{*}{1.2} & \multirow{2}{*}{$\begin{array}{l}\text { The bus are always running at a safe speed } \\
\text { and carry the passengers as per the specified } \\
\text { capacity }\end{array}$} & $\mathrm{N}$ & 102 & 173 & 40 & 70 & 0 \\
\hline & & $\%$ & 26.5 & 44.9 & 10.4 & 18.2 & 0 \\
\hline \multirow[t]{2}{*}{1.3} & \multirow{2}{*}{$\begin{array}{l}\text { Personnel in the bus stations have } \\
\text { knowledge and perform their activities } \\
\text { accurately and dependably }\end{array}$} & $\mathrm{N}$ & 83 & 131 & 91 & 80 & 0 \\
\hline & & $\%$ & 21.6 & 34 & 23.6 & 20.8 & 0 \\
\hline \multirow[t]{2}{*}{1.4} & \multirow{2}{*}{$\begin{array}{l}\text { Personnel in the bus station are friendly, } \\
\text { courteous and show willingness to help the } \\
\text { passengers }\end{array}$} & $\mathrm{N}$ & 87 & 160 & 50 & 68 & 20 \\
\hline & & $\%$ & 22.6 & 41.6 & 13 & 17.7 & 5.2 \\
\hline \multirow[t]{2}{*}{1.5} & \multirow{2}{*}{$\begin{array}{l}\text { Personnel in the bus stations provide prompt } \\
\text { services and explain the announcement of } \\
\text { delays of the buses }\end{array}$} & $\mathrm{N}$ & 93 & 192 & 10 & 90 & 0 \\
\hline & & $\%$ & 24.2 & 49.9 & 2.6 & 23.4 & 0 \\
\hline
\end{tabular}

Source: Computed from own survey data, 2019

In Table 4.2.1 indicated that 91(23.6\%) strongly disagree, 173(44.9\%) disagree 31(8.1\%) medium and $90(23.4 \%)$ were agree on the terminal has safe and competent drivers and Conductors. This reveals that majority of passengers were disagree on the terminal has safe and competent drivers and Conductors. Also, 102(26.5\%) strongly disagree, $173(44.9 \%)$ disagree $40(10.4 \%)$ medium and $70(18.2 \%)$ were agree on the bus are always running at a safe speed and carry the passengers as per the specified capacity. This also indicated the majority of 
respondents disagree on the bus are always running at a safe speed and carry the passengers as per the specified capacity. Furthermore, 83(21.6\%) strongly disagree, 131(34\%) disagree 91(23.6\%) medium and 80(20.8\%) were agree Personnel in the bus stations have knowledge and perform their activities accurately and dependably. This indicated the majority of respondents disagree on Personnel in the bus stations have knowledge and perform their activities accurately and dependably. More over table 4.4, 87(22.6\%) strongly disagree, 160(41.6\%) disagree 50(13\%) medium and 68(17.7\%) agree and 20(5.2\%) were strongly agree on Personnel in the bus station are friendly, courteous and show willingness to help the passengers. This indicated the majority of respondents disagree on Personnel in the bus stations have knowledge and perform their activities accurately and dependably and 93(24.2\%) strongly disagree, 192(49.9\%) disagree $10(2.6 \%)$ medium and 90(23.4\%) agree on Personnel in the bus stations provide prompt services and explain the announcement of delays of the buses. This indicated the majority of respondents disagree on personnel in the bus stations provide prompt services and explain the announcement of delays of the buses.

Table 4.2.2: Fare system

\begin{tabular}{|c|c|c|c|c|c|c|c|}
\hline & ITEM & & $\begin{array}{l}\text { Strongly } \\
\text { disagree }\end{array}$ & Disagree & Neutral & Agree & $\begin{array}{l}\text { Strongly } \\
\text { agree }\end{array}$ \\
\hline \multirow[t]{2}{*}{1} & \multirow{2}{*}{$\begin{array}{l}\text { I feel that the fares for the passengers } \\
\text { are affordable }\end{array}$} & $\mathrm{N}$ & 40 & 121 & 92 & 92 & 40 \\
\hline & & $\%$ & 10.4 & 31.4 & 23.9 & 23.9 & 10.4 \\
\hline \multirow[t]{2}{*}{2} & \multirow{2}{*}{$\begin{array}{l}\text { I believe that the fares for the } \\
\text { passengers are cost effective }\end{array}$} & $\mathrm{N}$ & 110 & 81 & 72 & 112 & 10 \\
\hline & & $\%$ & 28.6 & 21 & 18.7 & 29.1 & 2.6 \\
\hline \multirow[t]{2}{*}{3} & \multirow{2}{*}{$\begin{array}{l}\text { I feel that the fares for the passengers } \\
\text { are reasonably charged }\end{array}$} & $\mathrm{N}$ & 81 & 141 & 83 & 60 & 20 \\
\hline & & $\%$ & 21 & 36.6 & 21.6 & 15.6 & 5.2 \\
\hline \multirow[t]{2}{*}{4} & \multirow{2}{*}{$\begin{array}{l}\text { I know that the fares for the luggage } \\
\text { are reasonably charged }\end{array}$} & $\mathrm{N}$ & 104 & 150 & 61 & 20 & 50 \\
\hline & & $\%$ & 27 & 39 & 15.8 & 5.2 & 13 \\
\hline
\end{tabular}

Source: Computed from own survey data, 2019

In Table 4.2.2 indicated that 40(10.4\%) strongly disagree and agree, 121(31.4\%) disagree 92(23.9\%) medium and agree on the fares for the passengers are affordable. This reveals that majority of passengers were disagree onthe fares for the passengers are affordable. Moreover, 110(28.6\%) strongly disagree, 81(21\%) disagree $72(18.7 \%)$ medium and $112(29.1 \%)$ and $10(2.6 \%)$ were disagree fares for the passengers are cost effective. This also indicated the majority of respondents agree on the fares for the passengers are cost effective. Also, 81(21\%) strongly disagree, 141(36.6\%) disagree 83(21.6\%) medium and 60(15.6\%) agree and 20(5.2\%) were disagree on fares for the passengers are reasonably charged. This indicated the majority of respondents disagree on the fares for the passengers are reasonably charged. In table 4.4, 104(27\%) strongly disagree, $150(39 \%)$ disagree $61(15.8 \%)$ medium and 20(5.2\%) agree and 50(13\%)) were disagree on the fares for the luggage are reasonably charged. This indicated the majority of respondents disagree on the fares for the luggage is reasonably charged.

Table 4.2.3: Accessibility

\begin{tabular}{|l|l|l|l|l|l|l|l|}
\hline & ITEM & & $\begin{array}{l}\text { Strongly } \\
\text { disagree }\end{array}$ & Disagree & Neutral & Agree & $\begin{array}{l}\text { Strongly } \\
\text { agree }\end{array}$ \\
\hline 1 & The bus terminal is located at a & $\mathrm{N}$ & 101 & 214 & 20 & 20 & 30 \\
\cline { 2 - 8 } & $\%$ & 26.2 & 55.6 & 5.2 & 5.2 & 7.8 \\
\hline \multirow{2}{*}{2} & $\begin{array}{l}\text { There is conveyance available from my } \\
\text { house to bus terminal }\end{array}$ & $\mathrm{N}$ & 51 & 111 & 52 & 121 & 50 \\
\cline { 2 - 8 } & $\%$ & 13.2 & 28.8 & 13.5 & 31.4 & 13 \\
\hline
\end{tabular}

Source: Computed from own survey data, 2019

In Table 4.2.3 indicated that 101(26.2\%) strongly disagree and agree, 214(55.6\%) disagree 20(5.2\%) medium and agree, $30(7.8 \%)$ strongly agree on the bus terminal is located at a convenient locality. This reveals that majority of passengers were disagree the bus terminal is located at a convenient locality. Also, 51(13.2\%) strongly disagree, $111(28.8 \%)$ disagree $52(13.5 \%)$ medium, $121(31.4 \%)$ agree and 50(13\%) were strongly agree on there is conveyance available from my house to bus terminal. this also indicated the majority of respondents agree on there is conveyance available from my house to bus terminal. 
Table 4.2.4: Transport comport

\begin{tabular}{|c|c|c|c|c|c|c|c|}
\hline & ITEM & & $\begin{array}{l}\text { Strongly } \\
\text { disagree }\end{array}$ & Disagree & Neutral & Agree & $\begin{array}{l}\text { Strongly } \\
\text { agree }\end{array}$ \\
\hline \multirow[t]{2}{*}{1} & \multirow[t]{2}{*}{ The buses are always neat and clean } & $\mathrm{N}$ & 184 & 81 & 0 & 60 & 60 \\
\hline & & $\%$ & 47.8 & 21 & 0 & 15.6 & 15.6 \\
\hline \multirow[t]{2}{*}{2} & \multirow{2}{*}{$\begin{array}{l}\text { The seating arrangement in the buses is } \\
\text { comfortable }\end{array}$} & $\mathrm{N}$ & 20 & 100 & 84 & 131 & 50 \\
\hline & & $\%$ & 5.2 & 26 & 21.8 & 34 & 13 \\
\hline \multirow[t]{2}{*}{3} & \multirow{2}{*}{$\begin{array}{l}\text { The buses have enough windows placed with } \\
\text { glasses for proper ventilation for the } \\
\text { passengers }\end{array}$} & $\mathrm{N}$ & 81 & 0 & 30 & 193 & 81 \\
\hline & & $\%$ & 21 & 0 & 7.8 & 50.1 & 21 \\
\hline
\end{tabular}

Source: Computed from own survey data, 2019

In Table 4.2.4 indicated that $184(47.8 \%)$ strongly disagree, $81(21 \%)$ disagree $60(15.6 \%)$ agree and strongly agree on the buses are always neat and clean. This indicates that majority of passengers were strongly disagree on the buses are always neat and clean. Moreover, 20(5.2\%) strongly disagree, $100(26 \%)$ disagree $84(21.8 \%)$ medium, $131(34 \%)$ agree and 50(13\%) were strongly agree on the seating arrangement in the buses is comfortable. This also indicated the majority of respondents agree on the seating arrangement in the buses is comfortable. In table 4.7, 81(21\%) strongly disagree and agree, 30(7.8\%) medium, 193(50.1\%) were agree on the buses have enough windows placed with glasses for proper ventilation for the passengers. This indicated the majority of respondents disagree on the buses have enough windows placed with glasses for proper ventilation for the passengers.

Table 4.5: Terminal environment

\begin{tabular}{|c|c|c|c|c|c|c|c|}
\hline & ITEM & & $\begin{array}{l}\text { Strongly } \\
\text { disagree }\end{array}$ & Disagree & Neutral & Agree & $\begin{array}{l}\text { Strongly } \\
\text { agree }\end{array}$ \\
\hline \multirow[t]{2}{*}{1} & \multirow{2}{*}{$\begin{array}{l}\text { There are security personnel for the } \\
\text { safety of the passengers at the bus } \\
\text { stations }\end{array}$} & $\mathrm{N}$ & 90 & 163 & 52 & 80 & 0 \\
\hline & & $\%$ & 23.4 & 42.3 & 13.5 & 20.8 & 0 \\
\hline \multirow[t]{2}{*}{2} & \multirow{2}{*}{$\begin{array}{l}\text { Signs Boards about the information of } \\
\text { the buses are placed }\end{array}$} & $\mathrm{N}$ & 175 & 130 & 10 & 40 & 30 \\
\hline & & $\%$ & 45.5 & 33.8 & 2.6 & 10.4 & 7.8 \\
\hline \multirow[t]{2}{*}{3} & \multirow{2}{*}{$\begin{array}{l}\text { There are frequent announcements } \\
\text { about the information of the buses }\end{array}$} & $\mathrm{N}$ & 165 & 110 & 40 & 30 & 40 \\
\hline & & $\%$ & 42.9 & 28.6 & 10.4 & 7.8 & 10.4 \\
\hline \multirow[t]{2}{*}{4} & \multirow{2}{*}{$\begin{array}{l}\text { Personnel in the bus stations are caring, } \\
\text { inspire trust and confidence in } \\
\text { delivering services }\end{array}$} & $\mathrm{N}$ & 151 & 164 & 50 & 20 & 0 \\
\hline & & $\%$ & 39.2 & 42.6 & 13 & 5.2 & 0 \\
\hline
\end{tabular}

Source: Computed from own survey data, 2019

In Table 4.2.5 indicated that $90(23.4 \%)$ strongly disagree, $163(42.3 \%)$ disagree $52(15.5 \%)$ medium and $80(20.8 \%)$ were agree on there are security personnel for the safety of the passengers at the bus stations. This reveals that majority of passengers were disagree on there are security personnel for the safety of the passengers at the bus stations. In the same table, 175(45.5\%) strongly disagree, 130(33.8\%) disagree 10(2.6\%) medium and $40(10.4 \%)$ agree and 30(7.8\%) were strongly agree on Signs Boards about the information of the buses are placed. This also indicated the majority of respondents strongly disagree on Signs Boards about the information of the buses are placed. Moreover, $165(42.9 \%)$ strongly disagree, $110(28.6 \%)$ disagree $40(10.4 \%)$ medium and strongly agree and 30(7.8\%) were agree there are frequent announcements about the information of the buses. This indicated the majority of respondents strongly disagree on the three are frequent announcements about the information of the buses. In addition, 151(39.2\%) strongly disagree, 164(42.6\%) disagree 50(13\%) medium and 20(5.2\%) were agree on Personnel in the bus stations are caring; inspire trust and confidence in delivering services. This indicated the majority of respondents disagree on the Personnel in the bus stations are caring; inspire trust and confidence in delivering services. 
Table 4.6. Availability of the facilities.

\begin{tabular}{|c|c|c|c|c|c|c|c|}
\hline & ITEM & & $\begin{array}{l}\text { Strongly } \\
\text { disagree }\end{array}$ & Disagree & Neutral & Agree & $\begin{array}{l}\text { Strongly } \\
\text { agree }\end{array}$ \\
\hline \multirow[t]{2}{*}{1} & \multirow{2}{*}{$\begin{array}{l}\text { There are adequate physical facilities like } \\
\text { toilets, shower, drinking water etc. }\end{array}$} & $\mathrm{N}$ & 123 & 101 & 61 & 30 & 70 \\
\hline & & $\%$ & 31.9 & 26.2 & 15.8 & 7.8 & 18.2 \\
\hline \multirow[t]{2}{*}{2} & \multirow{2}{*}{$\begin{array}{l}\text { There are cafeteria, and food joints for } \\
\text { the facility of passengers around the } \\
\text { terminal }\end{array}$} & $\mathrm{N}$ & 124 & 181 & 0 & 40 & 40 \\
\hline & & $\%$ & 32.2 & 47 & 0 & 10.4 & 10.4 \\
\hline \multirow[t]{2}{*}{3} & \multirow{2}{*}{$\begin{array}{l}\text { There are bus shelters, seating } \\
\text { arrangements, parking spaces for waiting } \\
\text { passengers }\end{array}$} & $\mathrm{N}$ & 123 & 80 & 50 & 72 & 60 \\
\hline & & $\%$ & 31.9 & 20.8 & 13 & 18.7 & 15.6 \\
\hline \multirow[t]{2}{*}{4} & \multirow{2}{*}{$\begin{array}{l}\text { The terminal has proper lighting facilities } \\
\text { for the passengers during the night }\end{array}$} & $\mathrm{N}$ & 173 & 102 & 0 & 50 & 60 \\
\hline & & $\%$ & 44.9 & 26.5 & 0 & 13 & 15.6 \\
\hline
\end{tabular}

Source: Computed from own survey data, 2019

In Table 4.2.6 indicated that $123(31.9 \%)$ strongly disagree, $101(26.2 \%)$ disagree $61(15.8 \%)$ medium, $30(7.8 \%)$ agree and 70(18.2) were strongly agree on there are adequate physical facilities like toilets, shower, drinking water etc. This reveals that majority of passengers were strongly disagree on there are adequate physical facilities like toilets, shower, drinking water etc. In the same table, 124(32.2\%) strongly disagree, 181(47\%) disagree $40(10.4 \%)$ were agree and strongly agree on there are cafeteria, and food joints for the facility of passengers around the terminal. This also indicated the majority of respondents disagree on the cafeteria and food joints for the facility of passengers around the terminal. In addition, 123(31.9\%) strongly disagree, $80(20.8 \%)$ disagree $50(13 \%)$ medium and $72(18.7 \%)$ agree and $60(15.8 \%)$ were strongly agree on bus shelters, seating arrangements, parking spaces for waiting passengers. This indicated the majority of respondents strongly disagree on the bus shelters, seating arrangements, and parking spaces for waiting passengers. Moreover, $173(44.9 \%)$ strongly disagree, $102(26.5 \%)$ disagree $50(13 \%)$ agree and $60(15.6 \%)$ were strongly agree on the terminal has proper lighting facilities for the passengers during the night. This indicated the majority of respondents strongly disagree on the terminal has proper lighting facilities for the passengers during the night.

Table 4.2.7: Scheduled Timings

\begin{tabular}{|l|l|l|l|l|l|l|l|}
\hline & ITEM & & $\begin{array}{l}\text { Strongly } \\
\text { disagree }\end{array}$ & Disagree & Neutral & Agree & $\begin{array}{l}\text { Strongly } \\
\text { agree }\end{array}$ \\
\hline & The buses are always plying on time & $\mathrm{N}$ & 203 & 72 & 50 & 60 & 0 \\
\cline { 3 - 8 } & $\%$ & 52.7 & 18.7 & 13 & 15.6 & 0 \\
\hline & $\begin{array}{l}\text { Frequent services are available so that } \\
\text { waiting time is shorter }\end{array}$ & $\mathrm{N}$ & 143 & 120 & 22 & 60 & 40 \\
\cline { 2 - 8 } & $\%$ & 37.1 & 31.2 & 5.7 & 15.6 & 10.4 \\
\hline
\end{tabular}

Source: Computed from own survey data, 2019

In Table 4.2.7 indicated that 203(52.7\%) strongly disagree, $72(18.7 \%)$ disagree 50(13\%) medium and $60(15.6 \%)$ agree on the buses are always flying on time. This reveals that majority of passengers were strongly disagree on the buses are always flying on time. In the same table, 143(37.1\%) strongly disagree, 120(31.2\%) disagree, 22(5.7\%) medium, 60(15.6\%) agree, and 40(10.4) were strongly agree on there is conveyance available from my house to bus terminal. this also indicated the majority of respondents strongly disagree agree on the conveyance available from my house to bus terminal.

Table 4.2.8: Customer satisfaction on public transport

\begin{tabular}{|c|c|c|c|c|c|c|c|}
\hline & ITEM & & $\begin{array}{l}\text { Strongly } \\
\text { disagree }\end{array}$ & Disagree & Neutral & Agree & $\begin{array}{l}\text { Strongly } \\
\text { agree }\end{array}$ \\
\hline \multirow[t]{2}{*}{1} & \multirow{2}{*}{$\begin{array}{l}\text { I am satisfied with the services offered } \\
\text { by the public transport from Dawuro } \\
\text { bus station }\end{array}$} & $\mathrm{N}$ & 81 & 142 & 82 & 80 & 0 \\
\hline & & $\%$ & 21 & 36.9 & 21.3 & 20.8 & 0 \\
\hline \multirow[t]{2}{*}{2} & \multirow{2}{*}{$\begin{array}{l}\text { I intend to recommend my friends and } \\
\text { relatives to use public transport from } \\
\text { Dawuro bus station }\end{array}$} & $\mathrm{N}$ & 71 & 81 & 60 & 133 & 40 \\
\hline & & $\%$ & 18.4 & 21 & 15.6 & 34.5 & 10.4 \\
\hline \multirow[t]{2}{*}{3} & \multirow{2}{*}{$\begin{array}{l}\text { I will regularly use the public transport } \\
\text { from Dawuro bus station even in future }\end{array}$} & $\mathrm{N}$ & 40 & 90 & 50 & 123 & 82 \\
\hline & & $\%$ & 10.4 & 23.4 & 13 & 31.9 & 21.3 \\
\hline
\end{tabular}

Source: Computed from own survey data, 2019

In Table 4.2.8 indicated that $81(21 \%)$ strongly disagree, $142(36.9 \%)$ disagree $82(21.3 \%)$ medium and $80(20.8 \%)$ were agree on satisfied with the services offered by the public transport from Dawuro bus station. This reveals that majority of passengers were disagree satisfied with the services offered by the public transport from Dawuro bus station. In addition, 71(18.4\%) strongly disagree, 81(21\%) disagree, 60(15.6\%), 133(34.5\%) agree and $40(10.4 \%)$ strongly agree on recommend my friends and relatives to use public transport from Dawuro 
bus station. This also indicated the majority of respondents agree on recommend my friends and relatives to use public transport from Dawuro bus station. In the same table, 40(10.4\%) strongly disagree, 90(23.4\%) disagree $50(13 \%)$ medium and $123(31.9 \%)$ agree and $82(21.3 \%)$ were strongly agree on regularly use the public transport from Dawuro bus station even in future. This indicated the majority of respondents agree on the regularly use the public transport from Dawuro bus station even in future.

\subsection{Regression Analysis}

For this study the multiple linear regression models was employed. For the analysis of multiple linear regressions the customers satisfaction public transport was used as the dependent variables and the independent variables which included in the model were services provided, fare system, accessibility, transport comport, terminal environment, availability of the facility and scheduled timing.

Table 4.3.1: Model Summary

\begin{tabular}{|l|r|r|r|r|r|}
\hline Model & \multicolumn{1}{|c|}{$\mathrm{R}$} & R Square & Adjusted R Square & Std. Error of the Estimate & $\begin{array}{l}\text { Durbin- } \\
\text { Watson }\end{array}$ \\
\hline 1 & $.880^{\mathrm{a}}$ & .774 & .769 & .500 & 2.074 \\
\hline
\end{tabular}

a. Predictors: (Constant), Timing, Facility, Fare, Service, Comfort, Environment,

Accessibility

In the SPSS output, $\mathrm{R}$ shows the value of the multiple correlation coefficients between the dependent and the independent variables $(\mathrm{R}=.880)$ which represents strong correlation. Next column shows the coefficient of determination or correlation coefficient $\left(\mathrm{R}^{2}\right)$ which is the proportion of variation in the dependent variable that is explained by the seven independent variables which is 0.774 . So $77.4 \%$ of the variation in Customer satisfaction with public transportcan is explained by seven independent factors in the multiple linear regression models.

Adjusted Coefficient of determination or correlation coefficient squared is found to be 0.769 . This value indicates the loss of predictive power or shrinkage and tells us how much variance in the dependent variable would be accounted for if the model had been derived from the population Table 4. 15. The adjusted $R^{2}$ gives some idea about how well our model generalizes and ideally its value becomes the same or very close to the value of $R^{2}$. The difference for the model is small $(0.774-0.769=0.005)$ which is $0.5 \%$. This shrinkage means that if the model were derived from the population rather than a sample, it would account for approximately $0.005 \%$ less variance in the outcome. Therefore, the researcher concludes that this regression model has resulted in a significant prediction of the influencing factors of the Customer satisfaction with public transport.

Durbin Watson which is done for checking independence of errors tests serial correlation between errors. Durbin-Watson used to detect the presence of autocorrelation in residuals. The value of Durbin-Watson always lies between 0 and 4 . If the Durbin-Watson statistic is substantially less than 3 , there is evidence of positive serial correlation. As a rough rule of thumb, if Durbin-Watson is less than 1.0, there may be cause for alarm. The value in our analysis is 2.074 which is under the acceptable limit (1-3).

The ANOVA result shows whether the proportion of variance explained in the model summary is significant. It also tells whether the overall effect of the seven independent variables on customer satisfaction with public transport is significant. It shows the value of F statistics 184.020 at 7 and 377 degrees of freedom is statistically significant at $95 \%$ confidence which means that model is statistically significant in Table 4.16.

Table 4.3.2 Test of Hypothesis

\begin{tabular}{|l|l|c|l|l|}
\hline & \multicolumn{1}{|c|}{ Hypothesis statement } & p-value & \multicolumn{1}{|c|}{ Significance } & \multicolumn{1}{|c|}{ Result } \\
\hline $\mathbf{H 0}_{1}$ & $\begin{array}{l}\text { A service provided has no significant effect on } \\
\text { passenger's satisfaction in the study area. }\end{array}$ & .020 & Significant & Rejected \\
\hline $\mathbf{H 0}_{2}$ & $\begin{array}{l}\text { Access to service has no significant effect on } \\
\text { passenger's satisfaction in the study area }\end{array}$ & .000 & Significant & Rejected \\
\hline $\mathbf{H 0}_{3}$ & $\begin{array}{l}\text { Availability of facilities has no significant effect on } \\
\text { passenger's satisfaction in the study area }\end{array}$ & .000 & Significant & Rejected \\
\hline $\mathbf{H 0}_{4}$ & $\begin{array}{l}\text { scheduled timings has no significant effect on } \\
\text { passenger's satisfaction in the study area. }\end{array}$ & .000 & Significant & Rejected \\
\hline $\mathbf{H 0}_{5}$ & $\begin{array}{l}\text { Terminal environment has no significant effect on } \\
\text { passenger's satisfaction in the study area. }\end{array}$ & .000 & Significant & Rejected \\
\hline $\mathbf{H 0}_{6}$ & $\begin{array}{l}\text { H0: Transport comfort has no significant effect on } \\
\text { passenger's satisfaction in the study area }\end{array}$ & .000 & Significant & Rejected \\
\hline $\mathbf{H 0}_{7}$ & $\begin{array}{l}\text { : Fare system has no significant effect on } \\
\text { passenger's satisfaction in the study area }\end{array}$ & .002 & Significant & Rejected \\
\hline
\end{tabular}




\section{CONCLUSION AND RECOMMENDATIONS}

\subsection{Conclusion}

The basic focus of this study were analyzing determinants which affecting passenger's satisfaction in public transport services the case of Dawuroro bus station, SNNPRS, Ethiopia. The study has taken customer satisfaction with public transport as dependent variable and factors viz., services provided, fare system, Accessibility, Transport Comfort, terminal environment, availability of facilities, and Scheduled Timings as independent variable

Following conclusions can be derived from the finding of this study:

Fare system has the highest impact on customer satisfaction, followed by availability of facility, terminal environment, services provided, transport comport, accessibility and scheduled timing were found to be significantly affecting customer satisfaction with public transport. With respect to the problems that face passengers using public transport services steepness of the road, highest number of passengers, negative attitudes of the drivers profit orienteers of bus owners were major problems in public transport service. Out of seven variables included in model service provided, fares system, transport comport were negatively influence the customers satisfaction, whereas accessibility, terminal environment, availability of facility and scheduled timing were positively influence customer satisfaction.

Out of the seven hypothesis tested all of seven are accepted.

\subsection{Recommendations}

Based on findings by understanding factors that affect customers' satisfaction in public transport services and problems of the public transport services that would help policy makers to design and implement more effective methods customer satisfaction in public transport. The following possible policy implications are drawn:

$>$ To make the service more affordable and satisfy the requirements of customers as well as to be competent and profitable for the enterprise, flexible and affordable fare rate system should be encouraged. So, the zonal road and transport department should promote services that provided for the passengers.

$>$ To make the transport more comfortable the buses must be always maintained neat, clean and in proper good condition. The seating arrangement in the buses should be comfortable and special facilities. . So, the traffic police and other concerned bodies should focus on buses neat, cleanness and sitting arrangements

$>$ To make the service more reliable and convenient by plying on time, increasing the frequency of the services and by reducing waiting time as well as overcrowding, increasing the number of buses is and the continuous monitoring of the traffic police is critical issue.

$>$ The buses should be run by experienced and competent drivers in order to have safe journey and avoid accidents.

$>$ Personnel in the bus station should be friendly, courteous and show willingness to help the passengers and provide prompt services and explain the announcement of delays of the buses. So, administrates of the Dawuro, zonal transport services and traffic polices should have better to give training and aware drivers and bus owners to bring attitudinal change.

\subsection{Directions for Further Research}

In this study to measure the satisfaction of the public transport services only seven dimensions and it explained by $77.4 \%$. This indicates there could be some other relevant dimensions that that not included in this study. so, the future researches, should focus on more dimensions of factors that affect customer satisfaction with public transport services. Road suitability, poor communication, traffic corruption, etc which can influence customer satisfaction with public transport.

In addition, conducting a replication study in other service sector is important thing; for example in the agricultural sector, health, telecommunication service, education and others.

\section{REFERENCES}

Adris A, Putra1Jinca M, YaminBambangRiyanto, AgusTaufikMulyono (2014). The Satisfaction Analysis for the Performance of Public Transport Urban Areas International Refereed Journal of Engineering and Science, 3(8):38-44.

Abmann, D. \&Sieber, N. (2005). Transport in Developing Countries: Renewable Energy versus Energy Reduction? Transport Reviews, 25 (6), 719-738.

ADB \& ASEAN (2003).Regional Road Safety Program: Indonesia.(Country Report, Jakarta: ASEAN.

Ali AlphonsusNwachukwu (2014) Assessment of Passenger Satisfaction with Intra-City Public Bus Transport Services in Abuja, Nigeria. Journal of Public Transportation, 17(1):99-119.

Anable, J. (2005). 'Complacent car addicts' or 'aspiring environmentalist'? Identifying travel behaviour segments 
using attitude theory. Transport Policy, 12 (1), 65-78.

Andreassen, T.W. (1995). (Dis)satisfaction with public service: the case of public transportation. Journal of service marketing, 9 (5), 30-41.

Andaleeb, S. \& Ahmed, R., (2007).Reforming Inner city Bus Transportation in a Developing Country: A Passenger- Driven Model. Journal of Public Transportation, Vol.10,No.1, 2007. Bangladesh.

Antonucci, L. et al. (2014). Passenger satisfaction: A multi-group analysis.Quality and Quantity, 48(1), 337-345.

Anderson, W.S., L.S. Baggett and S.K. Widener, (2007). The impact of service operations failures on customer satisfaction: Evidence on how failures and their source affect what matters to customers. Manufacture.Service Operations. Management, 11: 52-69.

Asri, D.U. \&Hidayat, B. (2005). Current Transport Issues in Jakarta and Its Impact on environtment. Proceedings of the Eastern Asia Society for Transportation Studies, 5, 1792-1798.

AsnakeTadesse (2006) Road Freight Transport in Ethiopia with Special Emphasis on AddisAbaba - Djibouti Corridor. Addis Ababa University School of Graduate Studies June, 2006 Addis Ababa.

Armstrong - Write, A., 1993. Public Transport in Third WorldCities.London: HMSO Publications Centre. Bamford, C.G., \& Robinson, H., 1978. Geography of Transport:Aspect Geographies. Great Britain.

(Bell, et al., 2006).Transport is the means by which these activities occur; it is the cement that binds together communities and their activities.

Beirão, G. \&Sarsfield Cabral, J.A. (2007).Understanding attitudes towards public transport and private car: A qualitative study.Transport Policy, 14 (6), 478-489.

Bielen, F. and N. Demoulin, (2007). Waiting time influence on the satisfaction-loyalty relationship in services.Management Service Quality, 17: 174-193.

Bryman, A. and E. Bell, 2007.Business Research Methods. 2nd Edn., Oxford University Press, Oxford.

Budiono O. Astuti, (2009) Customer Satisfaction in Public Bus Transport: A study of travelers' perception in Indonesia. Master Thesis, Service science program, Karlstad University December 2005.

Budiono, O.A. (2009a). Mengapakitasusahmenggunakanangkutanumum.

Budiono, O.A. (2009b). Perceived Satisfaction in Public Transport.(Project for Master Thesis Work edn.). Karlstad.

Cavana, R.Y. and L.M. Corbett, 2007. Developing zones of tolerance for managing passenger rail service quality. International Journal of Quality Reliability Management., 24: 7-31.

Coakes, S.J. and L. Steed, 2007.SPSS Version 14.0 for Windows: Analysis without Anguish: Wiley. Disney, J., 1998. Competing through quality in transport services.Management Service Quality, 8: 112-118.

Cervero, R. (2000). Informal transport in the developing world.Jakarta: UN-HABITAT.

David NyongesaMurambi, Henry M. Bwisa (2014) Service quality and customer satisfaction in public transport sector of Kenya: A Survey of shuttle travelers in kitale terminus.International Journal of Academic Research in Business and Social Sciences, 4(9):1-11.

Department for Transport (2003).understanding customer needs. United Kingdom: UK Department for transport.

Daniels, P.W., 1993. Service Industries in the World Economy.Great Britain: Blackwell Publishers.

Denton, D., 1989. How to Give Quality Service to Your Customers.Texas: Gulf Publishing Company Houston.

De Oña, J., de Oña, R., Eboli L., \&Mazzulla, G. (2013). Perceived service quality in bus transit service: A structural equation approach. Transport Policy, 29, 219-226.

De Oña, J., de Oña, R., \&Calvo, F. J. (2012).A classification tree approach to identify key factors of transit service quality.Expert Systems With Applications, 39(12), 11164-11171.

Ekinci, Y., 2004. An investigation of the determinants of customer satisfaction. Tour Anal., 8: 197-203.

Esteban, A., N.A. Milla, A. Molina and D. MartinConsuegra, 2002.Market orientation in service: A review and analysis.European Journal of Market., 36: 1003-1021 .

Eboli L. \&Mazzulla G.(2007) Service Quality Attributes Affecting Customer Satisfaction for Bus Transit, University of Calabria.

Edvarsson, B. (1998). Causes of customer dissatisfaction - Studies of public transport by critical incident method.Managing Service Quallity, 8 (3), 189-197.

Ellaway, A., Macintyre, S., Hiscocl, R. \& Kearns, A. (2003). In the driving seat: Psychosicial benefits from private motor vehicle transport compared to public transport. Transportation Research Part F: Traffic Psychology and Behaviour, 6 , 217-231.

Ethiopia Road Authority (2005): Ethiopian National Urban Transport Policy, Urban Transport.

Ethiopian Federal Transport Authority (EFTA) (2011): The Directorate of Commercial Passenger Quality Certificate Office, July 2011.

Fellesson, M.F., Margareta (2008). Perceived Satisfaction with Public Transport Service in Nine European Cities.Journal of the Transportation Research Forum, 47 (3), 93- 103.

FikaduKassa (2014) Informal Transport and its Effects in the Developing World: A Case Study of Addis Ababa, Ethiopia.Arbaminch University, Brazilian Transportation Planning Society Journal of Transport Literature, 
Vol.8.No2 April.2014.

FikaduKassa, (2013) The Service Adequacy of Long Distance Bus Transport in Addis Ababa,Ethiopia: International Journal of Research in Advent Technology.

Fraenkel, J. and N. Wallen, (2003).How to Design and Evaluate Research in Education. 1st Edn.,McGrawHill, New York.

Friman, M. (1998).Satisfaction with public transport services.Diss. Karlstad: Högskolan I Karlstad.

Friman, M., Edvardsson, B. \&Gärling, T. (2001).Frequency of negative critical incidents and satisfaction with public transport services. I. Journal of Retailing and ConsumerServices, 8 (2), 95-104.

Friman, M. \&Gärling, T. (2001).Frequency of negative critical incidents and satisfaction with public transport services. II. Journal of Retailing and Consumer Services, 8 (2), 105-114. 